\title{
Introduction: Local Peacebuilding through a Gender Lens
}

\author{
Elisabeth Prügl, Rahel Kunz, Mimidoo Achakpa, Henri Myrttinen, Joy \\ Onyesoh, Arifah Rahmawati, Christelle Rigual and Wening Udasmoro
}

\begin{abstract}
Around the world, people and communities transform violent conflicts and build peace in various ways. Such local practices have been widely documented in various disciplines but have rarely been studied in the field of peace and conflict studies. These practices highlight the ways in which peacebuilding involves various axes of difference that intersect with one another, including gender, age, class, ethnicity, religion and political ideologies. Adopting a feminist approach, we analyse such intersecting differences to develop a better understanding of the multiple and complex ways in which gender is present in peacebuilding practices, and of how it both enables and obstructs transformative goals. We address the question: How does gender inform peacebuilding initiatives in intersection with other social dynamics and identity categories, and to what effect? Identifying a number of gender logics, we show how intersectionally gendered dynamics shape and are shaped by peacebuilding initiatives. We analyse how gender becomes productive either by being deployed strategically or by asserting itself inadvertently, for example through gender stereotypes, gendered divisions of labour, or identity constructions. We build on the outcomes of a six-year collaborative research project involving scholars from Indonesia, Nigeria and Switzerland that centred on investigating peacebuilding initiatives at local, meso-and macro-levels in Indonesia and Nigeria.
\end{abstract}

\section{Introduction}

People and communities around the world have a wealth of competence in managing and transforming violent conflicts. They foster links across religious, ethnic and ideological divides; bring to bear their authority as family members or government or community leaders to counteract enmity; creatively disrupt conflict and build relationships through their art; and organise politically to achieve inclusive societies. Their work recognises the power of gender, age, 
religion and other social dynamics to fuel othering, but also to function as a resource for building peace. People are assigned different roles in conflict and peacebuilding along various axes of difference that intersect with one another, including gender, age, class, ethnicity, religion and political ideologies. A feminist approach to peace and conflict studies brings into view such intersecting differences. It also trains our eye to people's diverse experiences of conflict and peacebuilding in the context of their communities, beyond the strategising of governments and insurgents. It thus provides a unique entry point to the exploration of local practices of conflict transformation and peacebuilding.

Such local practices have been widely documented in various disciplines and contexts, but have rarely been studied in the field of peace and conflict studies. Rather, in this context, peacebuilding has mostly been used to refer to international interventions in post-conflict societies, defined as 'all types and phases of international intervention aimed at political, legal, economic and social transformation of a war-torn state' (Duncanson, 2016, 4). This includes policies and programming that engage international organisations (including the United Nations and the World Bank), governments, and non-governmental and civil society organisations intent on constructing a peace, typically based on ideals of liberal governance (Campbell, Chandler and Sabaratnam, 2011; Paris, 2010). While sensitive to local contexts, such efforts remain decidedly top-down. Put simply, peace appears to be something that outsiders from the North bring to people from the South who seemingly have failed to keep violence at bay. Local actors, initiatives, and processes for peace in conflict-affected communities are often rendered invisible. This volume addresses this neglect and silencing through detailed analyses of local peacebuilding initiatives. This is not to suggest that peace can be built only locally or that gender matters only in local contexts. On the contrary; as much feminist scholarship shows, gender is pervasive in international relations on multiple scales (Sjoberg, 2013; 2008). We start, however, with the premise that peace cannot be built without regard for local power relations. These encompass local dynamics as well as political and economic processes originating on scales beyond the local.

In 2000, feminist lobbying led to the adoption of United Nations (UN) Security Council Resolution 1325, initiating what has become known as the UN's women, peace and security agenda (WPS). The expectation of feminists was that WPS would lead to a disruption of the patriarchal power relations that feed war and violence. With the implementation of this agenda, peacebuilding has come to encompass efforts to increase women's participation and to account for their gender-specific needs. But such efforts have tended to focus on including women, understood as a homogenous group, to the detriment of recognising the complexities of gender as an aspect of political and social 
relations (Duncanson, 2016; Hudson, 2012; Myrttinen, Naujokis and El-Bushra, 2014; Rigual, 2017; Speake, 2013). This is also the case for many initiatives that insist on 'engaging "local women"' (Väyrynen, 2010, 149). The effect of this has been to invisibilise gendered hierarchies and negotiations of gender identities. Moreover, efforts to implement the WPS agenda have largely remained too topdown (Shepherd, 2017). Taking the form of 'gender mainstreaming', they have approached gender equality as a problem amenable to technical solutions, failing to appreciate that transforming gender relations is a deeply political project. Efforts to include women in peacebuilding have thus often kept in place existing power relations and the violence they sustain.

Our starting point in this thematic volume is thus the role of gender rather than that of women in building peace. Our objective is to develop a better understanding of the multiple and complex ways in which gender is present in peacebuilding practices, and of how it both enables and obstructs transformative goals. We show how intersectionally gendered dynamics shape and are shaped by peacebuilding initiatives. We identify how gender becomes productive either by being deployed strategically or by asserting itself inadvertently, for example through gender stereotypes, gendered divisions of labour, or identity constructions. We acknowledge the importance of exploring women's initiatives-organising and mobilising for peace in their respective communities, as many scholars focusing on local peacebuilding have emphasisedand shed light on such activities. But we also examine the multiple and complex gendered dimensions of and challenges to peacebuilding, how gender is performed and reconstituted through peacebuilding practices, the effects of deploying gender as a technology of government, and what inclusive peace might look like.

The volume is an outcome of a six-year collaborative research project that, funded by the Swiss Programme for Research on Global Issues for Development (r4d), has investigated the gender dimensions of social conflict, armed violence and peacebuilding. ${ }^{1}$ The project has entailed close collaboration between scholars from Indonesia, Nigeria and Switzerland, who jointly conceptualised and implemented the research and who co-authored the contributions to this volume. While during the first half of the project we examined how gender

1 Funding by the Swiss National Science Foundation is gratefully acknowledged. Project Nr. 400240_1146777. See project website: https://www.graduateinstitute.ch/research-centres/ gender-centre/gender-dimensions-social-conflicts-armed-violence-and-peacebuilding (accessed on 17 May 2021). The project was conceptualised by Jana Krause based on her research project Resilient Communities: Non-Violence and Civilian Agency in Communal War (Krause, 2018). 
operates in conflict cycles, our focus during the second half was on peacebuilding activities. We approached the topic by focusing on locally emerging practices firmly anchored in conflict-affected communities and post-conflict settings in Indonesia and Nigeria. With long and diverse histories of both violent conflict and peacebuilding, the two countries provided us with rich material for analysis. Both shifted from authoritarian to democratic regimes at the turn of the century, and both subsequently witnessed violent conflict. Both are regionally diverse and violence has taken different forms, including communal conflicts, resource conflicts, and insurgencies. Both countries also have a vibrant civil society and a blossoming landscape of local peacebuilding activities.

Our research on peacebuilding started from a common question-How does gender inform peacebuilding initiatives in intersection with other social dynamics and identity categories and to what effect? We have explored peacebuilding initiatives at local, meso-and macro-levels, including community groups, nongovernmental organisations ( $\mathrm{NGOS}$ ), and state and international efforts linked to six subnational regions: Maluku, Aceh, and East Java in Indonesia, and Plateau State, Delta State, and Enugu in Nigeria. The absence of UN peacekeeping in these regions encouraged us to bring local agency to the fore-though such agency is rarely completely untouched by national and international policies and discourses. In addition to internationally brokered peace agreements (in the case of Aceh and the Niger delta), international development logics and neo-liberal economic orthodoxy have influenced the peacebuilding practices under investigation, highlighting the imbrication of national and international dynamics with local ideas and practices.

We aim to make a number of contributions to the existing literature. First, our volume features analyses of initiatives and agents of peacebuilding that have hitherto not received much attention. These include initiatives of political participation and activism, art-for-peace initiatives, livelihood initiatives aimed at peacebuilding, and community-building for peace, for example through traditional institutions. Our contributions look at these efforts through a gender lens, unpacking often-neglected dimensions of peacebuilding such as household dynamics, and making visible the way gender, in intersection with other axes of difference, supports or derails local efforts for peace.

Second, we self-consciously applied a feminist methodology to our research. This led us to identify peacebuilding initiatives through an inductive process of engaging with local activists and practitioners living in conflict-affected communities and post-conflict settings. It allowed us to explore the multiple, complex and ambiguous ways in which these agents have understood, experienced and practiced the links between gender and peace. In some instances, 

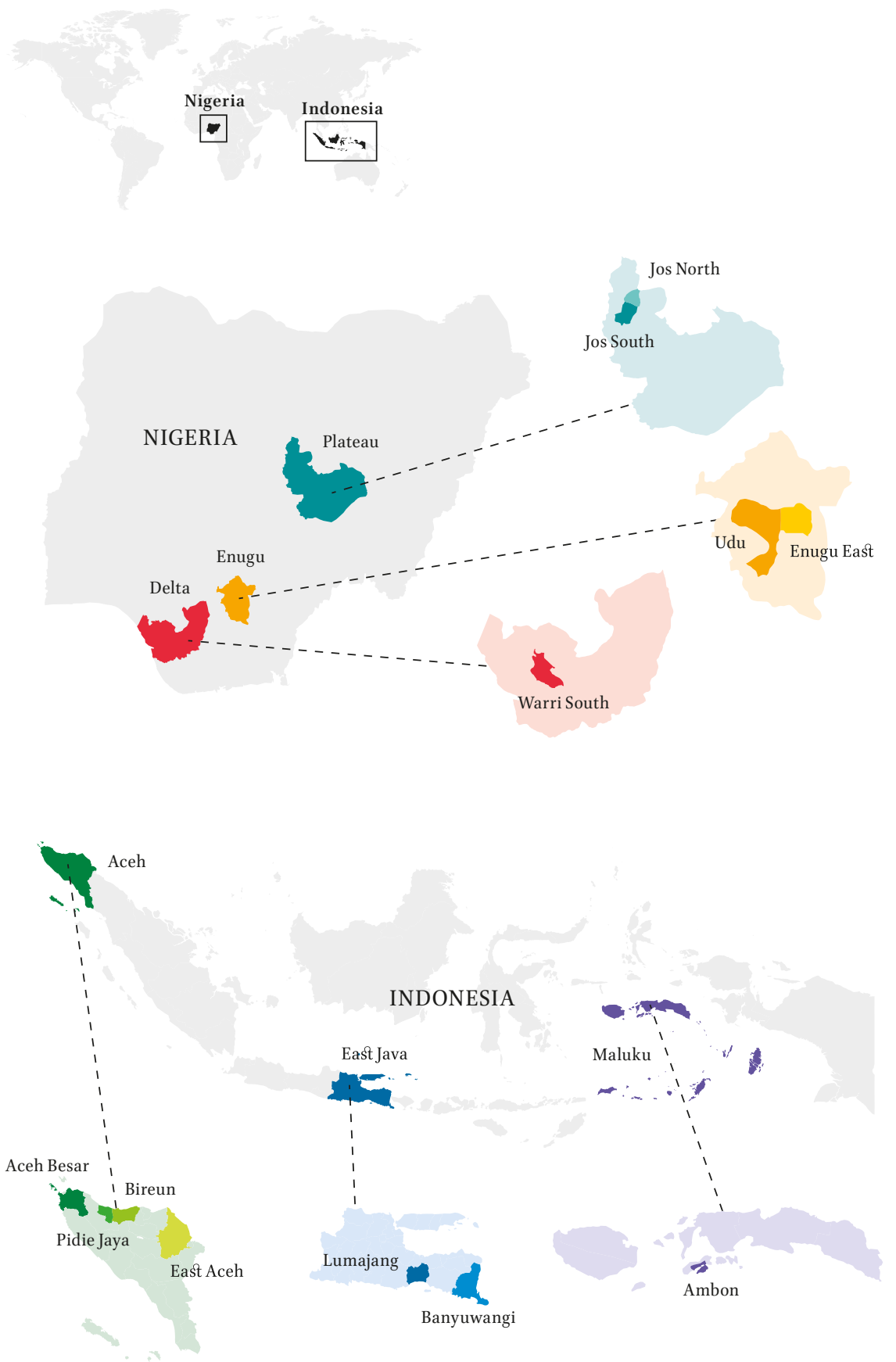

FIGURE 1.1 Situation of the research fields SOURCE: AUTHORS 
we became part of their efforts-initially by providing survivors and perpetrators an opportunity to tell their stories, giving them visibility. But we also supported some initiatives actively, thereby becoming part of peacebuilding efforts. While this erased the boundary between the researcher and the researched, which is often required in research designs that are meant to show objectivity, it allowed us to become partners of our research subjects, embrace their causes, and generate political impact through the process of research.

Third, this volume addresses calls by feminists for more collaborative research across North-South divides: it is still relatively rare to find such research, and in particular co-authored publications issuing from such research. The fact that we had financial support for the aforementioned partnership facilitated this collaboration. It also allowed for ongoing reflections and conversations regarding neo-colonial dynamics in South-North research projects, including the risk of extractive research practices. We sought to build a fair and equal partnership, based on trust and taking responsibility for establishing the necessary conditions for mutual learning and creativity in our research. Reflexivity on this matter was built into our project proposal and research design, drawing on the principles developed by the Swiss Commission for Research Partnerships with Developing Countries (KFPE). ${ }^{2}$

Fourth, we provide practical insights relevant to development, peace and security practices. Engaged in 'research for development', we want our findings to speak not only to scholars, but also to activists and practitioners in the fields of security, conflict management and peacebuilding. This has challenged us to put into practice feminist insights about the way theory is practical and praxis needs theory (compare to Prügl, 2020), for example by remaining wary of arriving too quickly at simplistic, universalising problem definitions and solutions. By untangling how peacebuilding is gendered in context and by identifying gender-sensitive peacebuilding initiatives, we hope to contribute to making peacebuilding thinking and practice more inclusive and more attuned to existing efforts in conflict-affected communities. We distil recommendations that derive from the unique combination of a nuanced theoretical approach to gender with concrete empirical insights collected through long-term, in-depth field research, knowledge co-developed within our international team, and a thorough consultative process carried out with the conflict-affected communities involved.

2 The KFPE is an information hub for North-South research in Switzerland. Its principles are explained on its website at https://kfpe.scnat.ch/en/11_principles_7_questions (accessed on 17 May 2021). 
The volume includes six chapters and two interludes. Each chapter provides a gender analysis of one distinctive initiative or practice in a specific context in either Indonesia or Nigeria. The interludes present reflections on, and experiences with, particular methodological issues that emerged during our collaborative research process. They focus, respectively, on the topics of sexual violence and experiences of field research, and deal with silences and issues that came up during 'side conversations' in the research process or during our research meetings, representing a reflexive analysis of our own research practices.

\section{Situating Local Peacebuilding Practices}

Our conceptualisation of peacebuilding combines approaches from both feminist and peacebuilding literature. We draw on insights from the 'local turn' in peacebuilding (Leonardsson and Rudd, 2015; Mac Ginty, 2014; Mac Ginty and Richmond, 2013; Randazzo, 2016) that has emerged as a reaction to topdown peacebuilding practices. Critical of the neo-colonial posture inherent in projects, which imposes liberal institutions of governance and neo-liberal economic policies, scholars have advocated paying attention to local agencies in order to increase the legitimacy of peacebuilding by encouraging a rethinking of authority, rights, and redistributions as a matter of everyday practice (Mac Ginty and Richmond, 2013, 769). These approaches recognise the scalar hybridity of peacebuilding; that is, the way in which international and national processes and interventions shape locally situated phenomena. In dialogue with the literature on the 'local turn', Rigual (2018) suggests that peacebuilding is a discursive formation that includes various bodies of academic scholarship providing explanations of war and associated visions, together with processes and programmes for peace. She argues the need for building bridges between the local turn in peacebuilding and the feminist focus on the everyday. This is what we attempt to do in this thematic volume. The feminist approach with which we align ourselves is based on a commitment to studying situated practice. It valorises local knowledge, explores intersectionally gendered practices, and carries a normative commitment to equality and inclusion.

Critical feminist scholarship on peace and conflict provides us insights into the relevance of gender in peacebuilding, including in intersection with other axes of difference (Cohn, 2012a; Confortini, 2010; Kappler and Lemay-Hébert, 2019b; Stavrevska and Smith, 2020; Väyrynen et al., 2021). It also pushes us to question simplistic dichotomies of violent conflict and non-violent peace and the supposedly 'natural' roles ascribed to and played by women and men in 
conflict and peace. Gender is not only a set of expectations linked to one's biological sex, but also as a system of power and of meaning-making (Confortini, 2010; Väyrynen et al., 2021). Such scholarship has documented women's work for peace in situated contexts, the activism of feminist peace movements, and gendered experiences of peacekeeping and peacebuilding from the perspective of marginal positionalities (Anderlini, 2007; Cockburn, 2007; Enloe, 1993; Flaherty et al., 2015; Kaufman and Williams, 2010 and 2016). Feminist scholarship also informs our methodology. Thus, studies of the local effects of the UN's women, peace and security agenda, remind us that the local cannot be thought of as a pristine site unaffected by politics (Firchow and Urwin, 2020; George and Soaki, 2020; Shepherd, 2020; Tamang, 2020). Understood as everyday social relations (rather than geography), the local is saturated with power relations, including political and economic processes originating on national and international scales (Mac Ginty, 2015; Massey, 1994). Moreover, for feminists the local is an epistemological position: it anchors standpoints and offers a situated context for co-creating knowledge in a way that is sensitive to epistemic power relations (Haraway, 1988; Harding, 2004).

A feminist understanding of peacebuilding focusing on local practices leads us to foreground particular kinds of processes and programmes. Liberal approaches tend to understand peacebuilding programmes as outside interventions that involve the international community (Paris, 2004) and follow 'a sequence of activities ranging from cease-fire to creating a new government and reconstructing the economy while bringing together former enemies' (Pruitt, $2013, \mathrm{xv}$ ). The focus tends to be on short-term initiatives that imagine peace as an outcome, a goal that can be achieved through targeted interventions. But feminist scholarship unveils the war/peace dichotomy that underlies this understanding as gendered, emphasising how violence describes a continuum and cannot be sorted into the containers of war and peace (Davies and True, 2015; Rigual, 2018, 9). Accordingly, peacebuilding is not a linear sequence of short-term initiatives, but must be understood as a long-term practice. Indeed, if war and peace cannot be convincingly separated, then perhaps peacebuilding needs to be conceptualised as an ongoing practice rather than a state of being or an outcome. From a feminist perspective, this practice needs to be evaluated normatively for the kind of 'peace' it establishes or performs.

Our empirical findings challenge us to adopt a broader understanding that is not limited to a linear sequence of peacebuilding and includes both shortand long-term elements. We show that peacebuilding happens, and is needed, in diverse spaces and temporalities, in different types and levels of conflict. We define peacebuilding as activities, conducted by a conflict-affected community or external (national and international) actors, intended to transform conflict, 
prevent the re/occurrence of violent conflict, and build non-violent relationships, including social and economic justice, within and beyond the community. This definition trained our focus on community relations and on the situated practices we wanted to foreground. It enabled a broad understanding of conflict as including not only killings, but also gender-based and other structural violences. It also enabled us to recognise the hybridity of initiatives, and led us to identify both local and extra-local actors and practices as being relevant for peacebuilding processes. Most of the initiatives we analyse in this volume do not have an explicit international dimension or involve international actors, but they often interact or engage with international dynamics in some ways. We collaborated with local actors to identify various peacebuilding practices, in this way recognising that the meaning of peace is ultimately negotiated in context (Bulduk, Onyesoh and Achakpa, this volume). We analyse these meanings through a number of gender logics that focus on the ways in which gender works in peacebuilding initiatives to create particular gendered forms of peace.

\section{How Does Gender Inform Peacebuilding and to What Effect?}

Feminist theories suggest that gender is a socially, culturally and historically specific construction. Gender performs what it means to be a human; it also structures societies, assigning value to institutions and practices. Constructivist theorising captures gendering as a process, including the productive force inherent in gender, the way in which gender drives identity formation, processes of institutionalisation, and symbolic imaginaries. Butler (2006) calls this the performativity of gender. As such, gender works as a regime that encodes hierarchy to produce social categories, practices and discourses, with complex power implications. The effect is to legitimise certain practices and delegitimise or silence others. Its binary logic contributes to framing discussions, research designs, and everyday forms of social interactions; it also silences non-binary, non-gender-conforming logics, groups and individuals.

Beyond the basic understanding of gender as a social construct, there is considerable variety in the way scholars employ the concept. Some seek to identify gendered structures and the constraints gender places on individual agency; others explore the gendering of identities through constructions of femininity and masculinity and the queering of these. Yet others emphasise the way gender has become an object of movement politics, the way gender inequality is contested, but also the way activists use gender constructions as a resource for peace politics. Finally, gender also has long been an object of governmental intervention, and is being deployed as a form of governmentality. 
These different understandings often complement rather than contradict one another. They provide us with routes via which we may conceptualise the role of gender in peacebuilding and thus answer our question regarding how gender shapes and is shaped by peacebuilding, and the effects it produces.

Gender does not work in isolation. It becomes productive in intersection with other social dynamics. This has particular relevance for conflict studies and for understanding the ways in which identities (based on nationality, ethnicity or religion) fuel violence (Cockburn, 2010; Kappler and Lemay-Hébert, 2019a). These axes of difference produce different effects. They can function to establish group identities, founding what scholars of civil war call fragmentation or fractionalisation. They can also act to modulate antagonisms among opposing groups, adding fuel to enmity or enhancing co-operation. The particularities of the way intersectional processes drive conflict cycles deserve considerably more empirical attention (Prügl and Rigual, 2018). Here we make a start by focusing on the way gender informs peacebuilding in an intersectional manner.

In the following, we introduce four logics to help us understand the workings of gender in peacebuilding initiatives: gender as a structuring, gender as an identity logic, gender as a resource for activism, and gender as governmentality. We identified these logics inductively in our examination of peacebuilding initiatives. They emphasise different aspects of the productivity of gender and draw on diverse feminist theorising with and beyond Butler. The first two logics address the non-conscious and habitual aspects of gender, the way it operates through social structures and internalised identity performances, what Giddens (2013) calls the 'practical consciousness' and Bourdieu calls a 'habitus' (Bourdieu and Wacquant, 1992). Intersectional dynamics are particularly salient when looking at peacebuilding from this perspective. In the second set of logics gender is performative in more conscious ways. It is mobilised for political goals, strategically deployed, and becomes a means of governmentality. Essentialisations often outweigh intersectional constructions when gender is used as a political resource in this way. The chapters in this thematic volume foreground these four logics of gender in different ways and to different degrees.

\subsection{The Structuring Logic of Gender}

The structuring logic of gender is perhaps the most familiar. It pertains to the way gendered dichotomies order modern social formations, including knowledge systems, labour relations and political and social practices (Lorber and Farrell, 1990). It not only produces female and male roles or spheres through processes of socialisation and institutionalisation, but also arranges them 
hierarchically, excluding and making invisible all that deviates from what is considered the standard. It produces a binary reality and constrains actors to operate within, and conform to, a certain set of representations. Some scholars describe this structuring logic as patriarchy, and emphasise the way in which it intersects with other logics. Thus, Cockburn (2010) explains war as resulting from the intersections of patriarchy, economic power, and ethnic or nationalist power.

The structuring logic of gender is apparent in the way the gendered opposition of war and peace informs research in Peace and Conflict Studies. It also guides practices of diplomacy and popular understandings of the relationship between women and peace. It shapes responses to conflicts by (in)visibilising certain groups and legitimising others, defining what are the proper or important dimensions to address in peacebuilding. It informs who is authorised to become a legitimate actor in political and peacebuilding processes, explaining why women continue to be so frequently excluded from decision-making processes and political representations across the globe and why women's participation is often limited to certain ('secondary') roles and issues, meaning that they often literally sit at different tables than men.

We encountered such structuring logics in the communities we explored in our research. Thus, community leaders in Delta State in Nigeria emphasised the importance of caring relations for peace and saw a particular role for mothers in helping to achieve 'harmony' Yet peacebuilding activists working in Delta encountered threatening behaviour when appearing to usurp power, and it was considered inappropriate for women to join vigilante groups (Bulduk, Onyesoh and Achakpa, this volume). In Aceh, women's secondary status during the insurgency became visible when female ex-combatants were excluded from economic and political benefits in post-conflict reintegration programmes unless they were close to elite men (Rahmawati, this volume). The structuring logic of gender thus (re)creates a division of labour and power in peacebuilding, where economic and political participation is reserved for men while women are denied jobs and are relegated to informal processes and to working at the grassroots level. It also serves to reproduce a binary and gendered construction of 'peace as the absence of war' that contradicts local understandings - including those articulate in our interviews in Deltathat define peace as including economic development (Bulduk, Onyesoh and Achakpa, this volume).

The structuring logic of gender generates inequalities and oppression, but sometimes also enables agency when patriarchal gender constructions assign distinctive powers to womanhood. In Jos, Nigeria, for example, women told us about 'checkmating' male family members, preventing them from joining 
communal violence. Although relegated to the private sphere, their authority as mothers and wives allowed them unique influence and peacebuilding agency (Rigual, Onyesoh and Udasmoro, forthcoming).

\subsection{The Identity Logic of Gender}

The structuring logic of gender finds a counterpart in individual performances of identity. Patriarchal structures fix social norms to establish oppositional and/or complementary male and female gender roles, creating the conditions for essentialising people's positions in society. Yet social norms never do fully determine. Rather, they are enacted by competent human beings that negotiate their agency vis-à-vis such norms. Gender identities also differ depending on social context. Moreover, stereotypical gender identities are enacted more or less faithfully, in this way reproducing, shifting, and challenging meanings. For example, women may perform repertoires and values culturally considered masculine, and men may fail to live up to hegemonic standards of masculinity. Sometimes, such 'mistaken' or creative performances risk becoming culturally unintelligible, generating various forms of social sanction. They also, however, play an important role in disturbing taken-for-granted patterns, sometimes disrupting the heteronormative gender order and with it the gendered meanings of war and peace.

A substantial body of literature shows how constructions of masculinity and femininity and logics of masculinist protection are foundational to enactments of armed violence and war (Cockburn and Zarkov, 2002; Cohn, 2012b; Duriesmith, 2016; Enloe, 1993; Young, 2003). Not surprisingly, such identity performances also sustain peacebuilding practices. They sometimes manifest as stabilising enactments of femininity, as in the case of the Umuada in Enugu, Nigeria, who draw on traditional constructions of what it means to be a first daughter for their activism (see Onyesoh, this volume). A similar logic is at work in Delta, where communities evoke the power of mothers to teach how to act peacefully (Bulduk, Onyesoh and Achakpa, this volume). But women peacebuilders also disturb traditional gender orders. This is certainly the case with female ex-combatants when they refuse to go back to traditional gender orders once the fighting has stopped, as with the Inong Balee in Aceh seeking to become politically active (Rahmawati, this volume). It is also the case for anti-land grab activists in East Java who disrupt conservative gender orders that relegated them to the domestic sphere by engaging in public protests and in sabotage against companies (see Udasmoro and Prügl, this volume). In both instances new opportunities emerge for shaping understandings and practices of peacebuilding in conjunction with redefinitions of femininity. 
The art-for-peace initiative in Ambon, analysed by Udasmoro and Kunz (this volume), offers interesting insights into the possibilities of genderdisruptive identity enactments for constructing a new peace. In the context of the initiative, youth from various backgrounds, including former combatants, draw on art to develop new identity performances that strikingly contradict the militarised masculinities that motivated them to fight. Moreover, their disruptions of gender are intimately linked to violating the boundaries of other intersecting identity formations, in particular ethnic and religious belongings. Embracing difference and building friendship through art is their strategy for transforming gender, ethnic, and religious performances in an effort to build peace, drafting new visions of identity and community.

\subsection{Gender as a Resource for Activism}

Describing gender as structuring and performative implies a quasi-habitual and unconscious enactment of its prescriptive force, but in the peacebuilding activities we examined we also found several instances where activists deliberately used existing gender constructions, applying them strategically to achieve various goals. Gender, or rather particular constructions of femininity and masculinity, in these contexts became a resource or tool for peacebuilding.

The use of 'strategic essentialism' for achieving political goals has been the focus of extensive discussion in feminist circles since Spivak (2006) introduced the concept. Within feminist peace movements, it has been employed particularly extensively in the form of maternalism — so, by drawing authority from discourses of motherhood (Cohn and Jacobson, 2012; Prasch, 2015). In our project, we encountered multiple strategic uses of this sort. For example, a powerful construction of femininity exists among the Igbos in Nigeria, where the Umuada are traditionally called on to resolve family and clan conflicts. Today, they are reinventing themselves, consciously taking advantage of their traditional authority to also engage in peacebuilding activism and charitable activities (see Onyesoh, this volume).

Contrasting these constructions of women as powerful, images of women's weakness can also become a resource for activism and peacebuilding. In East Java, for example, women were invited to move to the front of anti-land grab protests as a strategy for reducing violence against protesters. Social taboos against attacking women, and constructions of police as protectors of women, were mobilised consciously by women's activism (Udasmoro and Prügl, this volume). Such strategic use of notions of women's weakness problematically reproduces a devaluation of women. The activism it enables, however, can also lead to enlarging their political power. This was the case in East Java, where 
women were able to expand their political agency despite being also instrumentalised for other goals (Udasmoro and Prügl, this volume).

\subsection{Gender as Governmentality}

The strategic use of gender among peacebuilding activists has a counterpart among governments and international organisations (IO s). Called on to mainstream gender into their policies, and to implement the UN's women, peace, and security agenda, governments and Io s have developed policies and programming to foster goals of gender equality, supporting the creation of gender expertise (Kunz and Prügl, 2019) and turning gender into a form of governmentality (Prügl, 2011; Repo, 2015). Gender experts, including academics and government and non-governmental practitioners, establish problem definitions and solutions to govern gender. They frame issues in new ways and propose complementary solutions, thereby producing new understandings of the relationship between gender and peace. When taken into consideration in peacebuilding efforts and initiatives, gender expertise often ends up essentialising biological sex to push for more inclusivity for women in every dimension of peacebuilding.

In this volume, Rigual analyses a 'development for peace' project in Maluku that was jointly designed and implemented by three UN agencies. She shows that the project activated gendered stereotypes, portraying women as diligent and serious in order to affirm the project's gender character. Because target communities and policy officers alike held such stereotypes, women were more frequently selected as beneficiaries, reproducing pre-existing gender constructions. Yet the project also disrupted existing gender relations. Somewhat unusually, it identified economic development as a crucial terrain for peacebuilding, providing innovative problem definitions and solutions. Enabling women's economic participation had the effect of shifting local gendered norms: women beneficiaries of the co-operative initiative felt more confident in challenging leadership in their communities and collectively making their voices heard. Gender was thus reconstructed, and new power relations emerged for a newly gendered peace.

\section{4 \\ Summaries of the Contributions}

The gender logics outlined must be read as heuristic tools and there is obvious overlap. As a result, the contributions to this thematic volume often identify several logics at once. At the same time, each foregrounds different ways in which gender is productive, in intersection with other social dynamics, roughly 
illustrating the logics outlined. The contributions are arranged in a way that allows us to show the structuring and identity logics of gender first. This is followed by interludes reflecting on our research process. The remaining chapters then explore the logics that emphasise gender as a tool for activism and as a form of governmentality.

The reintegration of ex-combatants is a crucial part of peacebuilding. The first chapter, by Rahmawati, analyses how reintegration processes in Aceh worked out for female ex-combatants. It focuses on social dimensions, economic dimensions in terms of access to compensation funds, and political dimensions in terms of support for female ex-combatants' candidacy to the local parliament. The analysis finds that the reintegration process has benefited only a few and left out most female ex-combatants. Although female ex-combatants do not face social stigma, their access to the benefits of economic and political reintegration is strongly influenced by their kinship with and proximity to men in power. Thus, the structuring logic of gender has intersected with kinship and social status to produce unequal outcomes. This intersectional dynamic also created a hierarchy among the female ex-combatants, shaping their changing identities and forms of femininity. The chapter underscores the importance of paying attention to intersecting dimensions of equality and inclusivity in reintegration processes.

The second chapter, by Bulduk, Achakpa and Onyesoh, explores alternative visions of peace in Delta State, Nigeria. It juxtaposes visions identified through interviews with NGO s and community groups with academic theories of peace, and brings these into conversation with one another. It discusses an understanding of peace as an absence of both direct and indirect violence, and one that requires economic development. It also identifies a vision of harmonious living, which involves overcoming negative emotions, and draws on feminist literature to connect this vision to the concepts of maternal thinking and building relations of care. Finally, it identifies the idea that peace should be gender-inclusive and finds that the form of such inclusion is contested. Assessing visions of peace through a gender lens, the chapter argues that gender logics lead to a privileging of employment for young men, the reservation of maternal thinking to women, and a questioning of women's ability to truly contribute to vigilantism.

The volume's third chapter shifts the attention from the structuring to the identity logic of gender. In the context of the focus on 'everyday peacebuilding', the field of peace and conflict is increasingly interested in the use of art as a tool for peacebuilding. This contribution, by Udasmoro and Kunz, proposes a critical reading of the intersectional dynamics of art-for-peace initiatives. It focuses on the context of Ambon in Indonesia to analyse one 
particularly prominent art-for-peace initiative: the Paparisa Ambon Bergerak $(\mathrm{PAB})$ collective. In this initiative, youth from various contexts, including former combatants, come together across ethnic and religious divides, embrace differences, and draw on art to develop new identity performances in order to transform violent masculinities for peace. Through art projects, they also create new spaces for women's voices and denounce issues linked to genderbased violence in order to build a peaceful society. The analysis reveals how the identity logic of gender works intersectionally, and highlights the complex social power dynamics and individual and collective dimensions of artfor-peace activities.

Two interludes follow, providing reflections on the dynamics of NorthSouth research projects and on the way in which the topic of gender-based violence came up and sometimes inadvertently was silenced as our research progressed. Gendered power relations thus need reflection, even in a project that explicitly sets out to study such relations. The two interludes offer glimpses of the deliberate reflexivity that was built into our research project, as feminist methodologies require.

Ensuring that research is ethical and contributes to the reduction of inequalities, especially gendered, class-based, and racialised power imbalances, is a central tenet of such methodologies. The same, ideally, goes for peacebuilding processes. However, in spite of important and meaningful attempts to redress power imbalances, both academic research and peacebuilding work too often remain highly unequal endeavours. In the first interlude, Myrttinen examines how, as a transnational feminist research project, the researchers involved sought to develop and foster practices to counteract power imbalances, together with the communities involved in the research, and what this might mean for future research in the time of the Covid-19 pandemic. He illustrates how power imbalances between the global North and the global South are often inescapable, as both research and peacebuilding are in multiple ways entangled with broader power structures underpinned by patriarchy, militarism, neo-coloniality and neo-liberal capitalism. The interlude also provides some examples of how feminist-inspired research and peacebuilding function to create opportunities to analyse and question these power structures, to think and act beyond, and to develop less extractive and more emancipatory practices.

The second interlude, by Rigual, Myrttinen, Rahmawati and Achakpa, problematises the silencing of gender-based violence in our research. Violent conflicts tend to exacerbate forms and frequencies of such violence (OHCHR, 202O; Wood, 2014). Yet information on gender-based violence is notoriously difficult to collect, even more so during war, and in particular 
in contexts where cultural, religious and legislative arrangements consider such violence taboo and stigmatise survivors. The interlude provides reflections on how we dealt with snippets of evidence on gender-based violence that emerged during the research process in conflict-affected communities in Indonesia and Nigeria. It also discusses how we may have inadvertently silenced such evidence in the process of conducting our research and explores the multifaceted and complex social, economic, and political dimensions that may have contributed to the risk of such silencing. It provides insights into the gendered context that enabled this potential silencing effect in Indonesia and Nigeria. Finally, it reflects on some strategies adopted in this project and on possible pathways to a better integration of the sensitive but centrally important issue of gender-based violence in conflict research.

Two subsequent chapters illustrate different forms of women's activism for peace. Women's leadership and empowerment is the focus of the contribution by Udasmoro and Prügl. It interprets women's participation in protest movements in light of feminist understandings of peace as inherently agonistic and involving struggle. The chapter traces a shift from male to female leadership in the anti-land grab protests in Wongsorejo, East Java, arguing that they empowered women to enact everyday citizenship. It also traces the way in which gender was deployed strategically in this shift and how it informed performances of identity. During the Reformasi era, men led the protests, but women supported them in a subversive appropriation of the ideology of Ibuism. This gender division of protest has shifted, in part based on the idea that putting women at the front will ensure that protests are less violent. Yet this also enabled a political empowerment of women and raised their status in the household. The authors argue that the protests allowed women to establish themselves as rights-bearing citizens and as skilled politicians. As they renegotiated gender relations in their families and communities, their struggle over land rights became a struggle for recognition for a new kind of peace.

Onyesoh's chapter on the Umuada focuses on a traditional institution from the south-eastern region of Nigeria. The Umuada is a kin group comprised of the first daughter of a lineage. It has historically served as a forum for women to voice their concerns and even today plays a key role in performing rituals, such as those associated with burials. It also traditionally engages in arbitration and conflict de-escalation, and maintains a strong level of agency and respect in the community. Onyesoh argues that institutions such as the Umuada have changed with colonialism and the associated loss of status for women. But she shows how they have recently been revalued and can serve 
as a model for peacebuilding for women across Nigeria and beyond. Gender, here, emerges as a structure intersecting with lineage: it matters whether one is a daughter and thus part of the lineage, or a wife who has married into the lineage from the outside. Being a daughter conveys distinctive powers that have allowed the Umuada to emerge as political agents that strategically deploy their power to contribute to building peace within and between communities.

Complementing the empirical exploration of community-based peacebuilding initiatives in the preceding contributions, the chapter by Rigual zeroes in on the work of international organisations in Indonesia and Nigeria. It reviews programmes that have come to integrate the goals of peacebuilding and development in the two countries. It also provides an in-depth discussion of a nutmeg co-operative in Maluku, tracing situated impacts and effects. The chapter first assesses the extent of gender mainstreaming, finding that gender considerations are thoroughly integrated into Io strategy documents. Second, it analyses the meanings gender assumes as programmes are implemented, finding essentialising constructions of women and men in programme documents. Yet an in-depth exploration of the cooperative in Maluku also shows that women are economically and politically empowered through the co-operative, resulting in a disruption of conservative gender norms. Finally, the chapter shows how these programmes produce broader governmental effects: efforts to prevent and counter violent extremism have led to a shift of funding, which has starved existing peacebuilding programmes in other areas; and neo-liberal governance logics have led to an emphasis on efficiency over goals of building cohesion in programme evaluations.

Myrttinen concludes this volume of International Development Policy by discussing the implications of the findings from the individual chapters for policy and programming interventions, identifying pitfalls and opportunities for advancing projects of gender-sensitive peacebuilding.

This volume will have achieved its goal if it conveys to readers the wealth of existing practices for transforming violent conflict and building peace in diverse communities in Indonesia and Nigeria, and if readers come to recognise that such practices are saturated with intersecting power relations. One core dimension of such power relations is gender, which we show to be a potent force propelling outcomes along a spectrum of peace and violence. Attempts to manage conflict and build peace would do well to recognise the force of gender and harness it to their ends. 


\section{Acknowledgements}

We would like to thank the editors of International Development Policy for their support in elaborating this thematic volume, in particular Marie Thorndahl and Graziella Moraes Dias da Silva. Thanks also go to all the wonderful reviewers of the online author workshop in November 2020, Elise Féron, Marjaana Jauhola, Elizabeth Mesok and Silja Bára Ómarsdóttir. We also thank the copyeditors for their work.

\section{References}

Anderlini, S.N. (2007) Women Building Peace: What They Do, Why It Matters (Boulder, CO: Lynne Rienner Publishers).

Bourdieu, P. and L.J.D. Wacquant (1992) An Invitation to Reflexive Sociology (Cambridge, UK: Polity Press).

Campbell, S., D. Chandler and M. Sabaratnam (2011) A Liberal Peace? The Problems and Practices of Peacebuilding (London: Zed Books).

Butler, J. (2006) Gender Trouble (New York: Routledge).

Cockburn, C. (2010) 'Gender Relations as Causal in Militarization and War: A Feminist Standpoint', International Feminist Journal of Politics, 12(2), pp. 139-157, DOI:10.1080/ 14616741003665169..Cockburn, C. (2007) From Where We Stand (London: Zed Books).

Cockburn, C. and D. Zarkov (2002) The Postwar Moment: Militaries, Masculinities and International Peacekeeping, Bosnia and the Netherlands (London: Lawrence \& Wishart).

Cohn, C. (ed.) (2012a) Women and Wars: Contested Histories, Uncertain Futures, 1st ed. (Cambridge, UK; Malden, MA: Polity Press).

Cohn, C. (ed.) (2012b) Women and Wars: Contested Histories, Uncertain Futures (Hoboken: Wiley).

Cohn, C. and R. Jacobson (2012) 'Women and Political Activism in the Face of War and Militarization', in C. Cohn (ed.) Women and Wars (Cambridge, UK; Malden, MA: Polity Press), pp. 102-123.

Confortini, C.C. (2010) 'Feminist Contributions and Challenges to Peace Studies', Oxford Research Encyclopedia of International Studies, DoI: 10.1093/acrefore/ 9780190846626.013.47.

Davies, S.E. and J. True (2015) 'Reframing Conflict-Related Sexual and Gender-Based Violence: Bringing Gender Analysis Back In', Security Dialogue, 46(6), pp. 495-512, DOI: 10.1177/og67010615601389.

Duncanson, C. (2016) Gender and Peacebuilding (Hoboken: Wiley). 
Duriesmith, D. (2016) Masculinity and New War: The Gendered Dynamics of Contemporary Armed Conflict (London: Routledge).

Enloe, C. (1993) The Morning After: Sexual Politics at the End of the Cold War (Berkeley: University of California Press).

Firchow, P. and E. Urwin (2020) 'Not Just at Home or In the Grave: (Mis)Understanding Women's Rights in Afghanistan', Journal of Intervention and Statebuilding, pp. 1-20, DOI: 10.108 o/17502977.2020.1812893.

Flaherty, M.P., T.G. Matyók, S. Byrne and H. Tuso (eds.) (2015) Gender and Peacebuilding: All Hands Required (Washington, D.C.: Lexington Books).

George, N. and P. Soaki (2020) ' "Our Struggle, Our Cry, Our Sweat”: Challenging the Gendered Logics of Participation and Conflict Transition in Solomon Islands', International Feminist Journal of Politics, 22(4), pp. 572-593, DOI: 10.1080/ 14616742.2020 .1798798 .

Giddens, A. (2013) The Constitution of Society: Outline of the Theory of Structuration (Hoboken: Wiley).

Haraway, D. (1988) 'Situated Knowledges: The Science Question in Feminism and the Privilege of Partial Perspective', Feminist Studies, 14(3), pp. 575-599.

Harding, S.G. (ed.) (2004) The Feminist Standpoint Theory Reader: Intellectual and Political Controversies (Hove, UK: Psychology Press).

Hudson, H. (2012) 'A Double-Edged Sword of Peace? Reflections on the Tension between Representation and Protection in Gendering Liberal Peacebuilding, International Peacekeeping, 19(4), pp. 443-46o.

Kappler, S. and N. Lemay-Hébert (2019a) 'From Power-Blind Binaries to the Intersectionality of Peace: Connecting Feminism and Critical Peace and Conflict Studies', Peacebuilding, 7(2), pp. 16o-177, DOI: 10.108o/21647259.2019.1588456.

Kappler, S. and N. Lemay-Hébert (2019b) 'From Power-Blind Binaries to the Intersectionality of Peace: Connecting Feminism and Critical Peace and Conflict Studies', Peacebuilding (London: Routledge), 7(2), pp. 160-177, DoI: 10.1080/ 21647259.2019.1588456.

Kaufman, J.P. and K.P. Williams (2016) Women, Gender Equality, and Post-Conflict Transformation: Lessons Learned, Implications for the Future (Abington: Taylor \& Francis).

Kaufman, J.P. and K.P. Williams (2010) Women and War: Gender Identity and Activism in Times of Conflict (Sterling, VA: Kumarian Press).

Krause, J. (2018) Resilient Communities: Non-Violence and Civilian Agency in Communal War (Cambridge: Cambridge University Press), Dor: 10.1017/9781108675079.

Kunz, R. and E. Prügl (2019) 'Introduction: Gender Experts and Gender Expertise', European Journal of Politics and Gender, 2(1), DoI:10.1332/251510819X15471289106o77. 
Leonardsson, H. and G. Rudd (2015) 'The 'Local Turn' in Peacebuilding: A Literature Review of Effective and Emancipatory Local Peacebuilding', Third World Quarterly, 36(5), pp. 825-839, DOI:10.1080/01436597.2015.1029905.

Lorber, J. and S.A. Farrell (1990) The Social Construction of Gender (sAG E Publications). Mac Ginty, R. (2015) 'Where Is the Local? Critical Localism and Peacebuilding', Third World Quarterly, 36(5), pp. 840-856, Dor: 10.1080/o1436597.2015.1045482.

Mac Ginty, R. (2014) 'Everyday Peace: Bottom-up and Local Agency in ConflictAffected Societies', Security Dialogue (Thousand Oaks: SAGE), 45(6), pp. 548-564, DOI: $10.1177 / 0967010614550899$.

Mac Ginty, R. and O.P. Richmond (2013) 'The Local Turn in Peace Building: A Critical Agenda for Peace', Third World Quarterly, 34(5), pp. 763-783, DoI: 10.1080/ o1436597.2013.80075o.

Massey, D.B. (1994) Space, Place, and Gender (Minneapolis: University of Minnesota Press).

Myrttinen, H., J. Naujokis and J. El-Bushra (2014) Re-Thinking Gender in Peacebuilding (International Alert), http://international-alert.org/sites/default/files/Gender_ RethinkingGenderPeacebuilding_EN_2014.pdf (accessed on 5 May 2016).

oнCHR (United Nations Human Rights Office of the High Commissioner) (2020) Women's Human Rights and Gender-Related in Situations of Conflict (Geneva: O HC HR) https://www.ohchr.org/en/Issues/Women/WRGS/Pages/PeaceAndSecurity.aspx (accessed on 17 October 2020).

Paris, R. (2010) 'Saving Liberal Peacebuilding', Review of International Studies, 36(o2), pp. 337-365, DOI: 10.1017/So26o21051000oo57.

Paris, R. (2004) At War's End. Building Peace After Civil Conflict. (Cambridge: Cambridge University Press), http://www.cambridge.org/ch/academic/subjects/politicsinternational-relations/international-relations-and-international-organisations/ wars-end-building-peace-after-civil-conflict (accessed on 4July 2016).

Prasch, A.M. (2015) 'Maternal Bodies in Militant Protest: Leymah Gbowee and the Rhetorical Agency of African Motherhood, Women's Studies in Communication (Routledge), 38(2), pp. 187-205, DOI: 10.1080/07491409.2014.993105.

Prügl, E. (2020) 'Feminist Methodology between Theory and Praxis', Review of International Studies, 46(3), pp. 304-314, D OI: 10.1017/So26o210519000482.

Prügl, E. (2011) 'Diversity Management and Gender Mainstreaming as Technologies of Government', Politics \& Gender, 7(1), pp. 71-89, Do I: 10.1017/S1743923X10000565.

Prügl, E. and C. Rigual (2018) A Feminist Constructivist Approach to the Study of Violent Conflicts, Paper presented at the Swiss Political Science Association Annual Conference, Geneva, 5-6 February.

Pruitt, L.J. (2013) Youth Peacebuilding: Music, Gender, and Change (Albany, NY: SUnY Press). 
Randazzo, E. (2016) 'The Paradoxes of the 'Everyday': Scrutinising the Local Turn in Peace Building', Third World Quarterly, 37(8), pp. 1351-1370, DoI: 10.1080/ 01436597.2015.1120154.

Repo, J. (2015) The Biopolitics of Gender (Oxford, New York: Oxford University Press).

Rigual, C. (2018) 'Rethinking the Ontology of Peacebuilding. Gender, Spaces and the Limits of the Local Turn', Peacebuilding, 6(2), pp. 144-169, DoI: 10.1080/ 21647259.2018.1453640.

Rigual, C. (2017) 'Putting the Local Turn in Motion? Toward a Gender Turn in Peacebuilding', in European Conference on Politics and Gender (ECPG: Lausanne).

Rigual, C., J. Onyesoh, and W. Udasmoro (Forthcoming) 'Gendered Authorities and Solidarities in the Management of Ethno-religious Conflicts', International Feminist Journal of Politics.

Shepherd, L.J. (2020) 'Situating Women, Peace and Security: Theorizing from "the Local", International Feminist Journal of Politics, 22(4), pp. 456-461, DOI: 10.1080/ 14616742.2020 .1796262 .

Shepherd, L.J. (2017) Gender, UN Peacebuilding, and the Politics of Space: Locating Legitimacy (Oxford: Oxford University Press).

Sjoberg, L. (2020) 'Situating Women, Peace and Security: Theorizing from "the Local" ', International Feminist Journal of Politics, 22(4), pp. 456-461, D OI: 10.1080/ 14616742.2020 .1796262$.

Sjoberg, L. (2008) 'Scaling IR Theory: Geography's Contribution to Where IR Takes Place', International Studies Review, 10(3), pp. 472-500, https://www.jstor.org/stable/25481989.

Speake, B. (2013) 'A Gendered Approach to Peacebuilding and Conflict Resolution', EInternational Relations, http://www.e-ir.info/2013/o2/11/a-gendered-approach-topeacebuilding-and-conflict-resolution/ (accessed on 9 November 2017).

Spivak, G.C. (2006) In Other Worlds: Essays in Cultural Politics (New York and London: Routledge).

Stavrevska, E.B. and S. Smith (2020) 'Intersectionality and Peace', in The Palgrave Encyclopedia of Peace and Conflict Studies (Cham: Springer International Publishing), pp. 1-8, DoI:10.1007/978-3-030-11795-5_120-1.

Tamang, D. (2020) 'Rethinking "Participation" in Women, Peace and Security Discourses: Engaging with "Non-Participant" Women's Movements in the Eastern Borderlands of India', International Feminist Journal of Politics, 22(4), pp. 485-503, DOI: 10.108 o/14616742.2020.1803098.

Väyrynen, T. (2010) 'Gender and Peacebuilding', in Richmond, O.P. (ed.) Palgrave Advances in Peacebuilding: Critical Developments and Approaches, Palgrave Advances (London: Palgrave), pp. 137-153, DOI: 10.1057/9780230282681_8.

Väyrynen, T., S. Parashar, É. Féron and C.C. Confortini (eds.) (2021) Routledge Handbook of Feminist Peace Research, ist edition (New York: Routledge). 
Wood, E.J. (2014) 'Conflict-Related Sexual Violence and the Policy Implications of Recent Research', International Review of the Red Cross (Cambridge: Cambridge University Press), 96(894), pp. 457-478, Dor: 10.1017/S1816383115000077.

Young, I.M. (2003) 'The Logic of Masculinist Protection: Reflections on the Current Security State', Signs, 29(1), pp. 1-25, DOI: 10.1086/375708. 